NANAEKE

Indonesian Journal of Early Childhood Education

Volume 4, Nomor 2, Desember 2021

\title{
PEMBELAJARAN ANAK USIA DINI ERA NEW NORMAL DI KABUPATEN PATI
}

\author{
Ahmad Nashiruddin \\ Institut Pesantren Mathali'ul Falah, \\ nashir@ipmafa.ac.id \\ Sumiyati \\ Institut Pesantren Mathali'ul Falah, \\ atikpaudi@gmail.com
}

\begin{abstract}
Abstrak
Pendidikan anak usia dini termasuk sektor yang terdampak pandemi covid-19 secara serius khususnya di wilayah Kabupaten Pati. Penelitian ini bertujuan untuk melihat seperti apa praktek pembelajaran anak usia dini yang ada di Kabupaten Pati selama era new normal. Penelitian ini dilakukan secara deskriptif kualitatif dengan metode pengambilan datanya menggunakan wawancara, observasi dan dokumentasi. Adapun analisis data menggunakan teori Miles dan Huberman dengan keabsahan data menggunakan triangulasi data. Hasil survey menunjukkan bahwa pembelajaran PAUD dibagi menjadi 2. Bagi Lembaga yang di bawah naungan Dinas Pendidikan masih full daring, sedangkan yang di bawah naungan Kementerian Agama, sudah mulai tatap muka terbatas, seperti kelas kunjung, shift pembelajaran, dan lain sebagainya.
\end{abstract}

Kata Kunci: Anak Usia Dini, New Normal, Pembelajaran,

\begin{abstract}
Early childhood education is a sector that has been seriously affected by the COVID-19 pandemic, especially in Pati Regency. The study aimed to describe the practice of early childhood learning in Pati Regency during the pandemic as the new normal era. The study was qualitative and descriptive with data collection methods using interviews, observation, and documentation. The data analysis used the theory of Miles and Huberman with data triangulation. The survey shows that PAUD has two learning practices. All institutions under the Education affairs are still fully online, while those under the Ministry of Religious affairs have limited face-to-face meetings, such as visiting classes, learning shifts, etc.
\end{abstract}

Keywords: Early Childhood, New Normal, Learning,

\section{PENDAHULUAN}

Berdasarkan Undang-undang Nomor 20 Tahun 2003 tentang sistem Pendidikan nasional menyebutkan jika pendidikan merupakan usaha sadar dan terencana untuk 
mewujudkan suasana belajar dan proses pembelajaran agar peserta didik secara aktif mengembangkan potensi dirinya untuk memiliki kekuatan spiritual keagamaan, pengendalian diri, kepribadian, kecerdasan, akhlak mulia, serta ketrampilan yang diperlukan dirinya, masyarakat, bangsa dan negara. Samino menyatakan bahwa pendidikan merupakan usaha sadar yang dilakukan oleh orang dewasa (pendidik) kepada orang yang belum dewasa (peserta didik) untuk memperoleh kedewasaan, baik dewasa secara rohani, jasmani, maupun sosial (Samino, 2010, p. 37). Beberapa pendapat yang telah para ahli sampaikan di atas memiliki arti jika Pendidikan merupakan sebuah usaha yang dilakukan secara sadar oleh orang-orang dewasa yang memiliki kompetensi di bidangnya, kepada orang-orang yang belum dewasa, supaya mereka dapat mengembangkan kemampuan akademis, keahlian, spiritual, dan sosialnya.

Sebuah pendidikan sangat erat dengan adanya peserta didik dan pendidik sehingga terjadi suatu proses pembelajaran. Menurut Gagne dalam Warsita, pembelajaran ialah suatu usaha untuk membuat peserta didik belajar atau suatu kegiatan untuk membelajarkan peserta didik (Warsita, 2011, p. 67). Sedangkan Sadiman menyatakan bahwa pembelajaran adalah suatu proses yang kompleks yang terjadi pada semua orang dan berlangsung seumur hidup sejak ia masih bayi sampai ke liang lahat (Arif S.Sadiman, 2014, p. 94).

Pembelajaran merupakan suatu sistem atau proses membelajarkan terhadap suatu subyek yaitu peserta didik yang direncanakan atau didesain, dilaksanakan, dan dievaluasi secara sistematis agar pembelajar dapat mencapai tujuan pembelajaran secara efektif dan efisien. (Komalasari, 2013, p. 2). Sedangkan proses pembelajaran merupakan proses komunikasi, yakni proses penyampaian pesan dari sumber pesan melalui saluran/media tertentu kepada penerima pesan. Pesan, sumber pesan, saluran/media dan penerima pesan adalah komponen proses komunikasi. Adapun proses yang akan dikomunikasikan adalah isi ajaran ataupun didikan yang ada di dalam kurikulum, sumber pesannya bisa berupa guru, peserta didik, orang lain, ataupun media (Komalasari, 2013, p. 8).

Terkait dengan pembelajaran yang biasanya dari tahun ke tahun yang lalu dilakukan secara penuh di lembaga pendidikan atau di sekolah, yang proses pembelajarannya melibatkan antara pendidik/guru dengan peserta didik. Tetapi sekarang dengan adanya Pandemi Covid-19, pemerintah membuat kebijakan untuk semua peserta didik mulai dari Pendidikan Anak Usia Dini (PAUD) sampai mahasiswa agar mematuhi peraturan pemerintah yaitu untuk melaksanakan kegiatan pembelajaran dari rumah atau belajar dari rumah yang disingkat dengan BDR selama masa normal baru (new normal). Program belajar dari rumah dilaksanakan secara dalam jaringan (daring) di rumah masing-masing peserta didik guna mengurangi penyebaran virus corona yang sedang melanda di seluruh lapisan masyarakat Indonesia (Yovita, 2020). Jadi bisa diambil pengertian jika selama masa pandemi ini, pembelajaran yang biasanya terjadi secara langsung antara guru dan murid di kelas, 
kini berganti dengan interaksi melalui media, baik itu handphone, maupun laptop. Hal ini dimaksudkan untuk mengurangi aktivitas bertemu secara fisik, untuk meminimalisir penyebaran virus.

Situasi ini tentu menyulitkan banyak pihak, tak terkecuali lembaga pendidikan anak usia dini yang harus juga menanggung dampaknya. Hal ini mengingat harus ada metode-metode pembelajaran baru yang sesuai bagi anak-anak usia dini. Dalam arti setiap institusi diharapkan mampu memberikan inovasi terbaru untuk membentuk proses pembelajaran yang sangat efektif ini. Sayangnya, tidak semua institusi pendidikan rupanya paham betul mengenai inovasi terbaru yang harus dipakai untuk melakukan pembelajaran selama era new normal. Banyak dari lembaga pendidikan yang masih belum bisa untuk menyesuaikannya karena terkendala berbagai hal, misalnya kualitas sumber daya manusianya ataupun sarana dan prasarana. Selain itu juga masih banyak yang bingung tentang bagaimana memberikan materi kegiatan atau pendidikan pada anak usia dini yang prinsip belajarnya adalah melalui bermain, berorientasi pada perkembangan anak, berorientasi pada kebutuhan anak, berpusat pada anak, berpusat pada pengembangan kecakapan hidup, berorientasi pada pengembangan nilai-nilai karakter, anak adalah pembelajar aktif (Montessori, 2017, p. 2).

Pentingnya pendidikan di masa usia dini adalah untuk membekali sedini mungkin pendidikan secara akademis dan keterampilan, agar anak dalam perjalanan di kehidupannya nanti dapat menjalani kehidupan dengan baik. Bukan secara akademis saja yang ditekankan, tetapi juga tentang agama dan moral, kognitif, fisik motorik, bahasa, sosial emosional, dan seni. Oleh karena itu berbagai hal yang diterima oleh anak pada usia dini akan menjadi pondasi dasar yang sangat bermanfaat bagi kehidupannya kelak. Sebagaimana yang telah tercantum dalam Peraturan Menteri Pendidikan dan Kebudayaan Republik Indonesia Nomor 146 tahun 2014 pasal 1, tentang Pendidikan Anak Usia Dini yang menyatakan bahwa:

“Pendidikan Anak Usia Dini yang selanjutnya disingkat PAUD, merupakan suatu upaya pembinaan yang ditujukan kepada anak usia sejak lahir sampai usia 6 tahun yang dilakukan melalui pemberian rangsangan pendidikan untuk membantu pertumbuhan dan perkembangan jasmani dan rohani agar anak memiliki kesiapan dalam memasuki pendidikan yang lebih lanjut".

Lantas bagaimana praktek pembelajaran Anak Usia Dini di Kabupaten Pati? Apakah kegiatan belajar mengajar pada anak usia dini tetap bisa berjalan meskipun saat pandemi Covid-19 seperti saat ini? Apa saja faktor-faktor yang memengaruhinya?Pertanyaan-pertanyaan seperti inilah yang nantinya akan mencoba peneliti temukan jawabannya dalam penelitian ini, khususnya yang berkaitan dengan pembelajaran anak usia dini di Kabupaten Pati era New Normal. 


\section{METODE PENELITIAN}

Jenis penelitian pada penelitian ini adalah penelitian kualitatif deskriptif yang menggunakan metode analisis data secara kualitatif karena dengan metode tersebut dapat menggambarkan dan memaparkan hasil penelitian berupa keadaan atau peristiwa dari suatu objek sebagaimana adanya.

Sesuai judul penelitian ini, maka peneliti akan mendeskripsikan, menguraikan dan menggambarkan secara jelas dan rinci serta menggunakan data yang mendalam dan fokus tentang permasalahan yang akan dibahas berkenaan dengan model pembelajaran anak usia dini selama era new normal.

Adapun sumber data utama dalam penelitian kualitatif adalah kata-kata dan tindakan, selebihnya adalah data tambahan seperti dokumentasi kegiatan dan lainlain. Data dapat dibedakan menjadi dua, yaitu data Primer dan data Sekunder. Data primer adalah data yang diperoleh dan dikumpulkan langsung dari sumber pertama melalui wawancara dan observasi (pengamatan) baik langsung maupun tidak langsung. Berkaitan dengan hal tersebut, maka wawancara dilakukan pemangku kebijakan pendidikan anak usia dini di Kabupaten Pati, Himpunan Pendidik PAUD, guru-guru, dan stakeholder terkait lainnya. Sedangkan sumber data yang diperoleh melalui observasi adalah pengamatan terhadap pelaksanaan kegiatan pembelajaran selama new normal. Sumber data sekunder merupakan sumber data pendukung dari sumber data primer. Data sekunder dapat diperoleh dengan mengambil bahan-bahan melalui literatur seperti buku ajar, arsip pembelajaran, fotofoto, dan lain-lain yang ada kaitannya dengan penelitian di atas.

Sedangkan teknik atau metode pengumpulan data dilakukan dengan menggunakan teknik observasi, dokumentasi, dan wawancara. Adapun untuk teknik analisis data menggunakan model analisis interaktif yang mencakup tiga komponen yang saling berkaitan, yaitu pengumpulan data, reduksi data, penyajian data dan penarikan kesimpulan. Sealin itu untuk keabsahan data dalam penelitian ini menggunakan teknik triangulasi. yaitu dengan memanfaatkan sumber data, metode, dan teori untuk dipadukan (Sugiyono, 2010, p. 125)

\section{HASIL DAN PEMBAHASAN}

Berdasarkan hasil wawancara dengan ketua Himpunan Pendidik dan Tenaga Kependidikan Anak Usia Dini (Himpaudi) Kabupaten Pati, Hj. Nur Laeli, SPd mengungkapkan jika selama masa pandemi pembelajaran di setiap jenjang pendidikan anak usia dini di Kabupaten Pati masih menggunakan sistem daring atau online. Hal ini mengikuti dari surat-surat edaran yang diikeluarkan oleh Bupati Pati terkait dengan pembelajaran selama era new normal. Misalnya berdasarkan Surat Edaran Bupati Pati Nomor 443.1/037 tentang pemberlakuan pembatasan kegiatan masyarakat untuk pengendalian penyebaran covid-19 di Kabupaten Pati, yang salah satu poinnya berbuyi "kegiatan belajar mengajar dilakukan secara daring/online di seluruh lini jenjang Pendidikan”. 
1. Pemerintah Kabupaten Pati memberlakukan Pembatasan Kepiatan Masyarakat mulai tanggal 11 Jnnuari 2021 sampai dengan 25 Jnnuari 2021.

2. Kegiatan Masyarakat di seluruh wilayah Kabupaten Pati dibatasi sampai tengan pukul 21.00 WIB.

3. Membatasi aktifitas di tempat kerja/perkantoran dengan menerapkan Work From Home (WFil) sebesar 75\% (tujuh puluh lima persen) dan Work From Office (WFO) sebesar $25 \%$ (dua puluh lima persen) dengan memberlakukan protokol keschatan secara lebih ketat, kecuali di tempat-tempat pelayanan keschatan (Rumah Sakit, Puskesmas, Klinik dan Tempat Pelayanan keschatan lainnya) serta tempat Pelayanan publik.

4. Sclama pclaksanaan masa pembatasan kegiatan masyarakat, tidak diperkenankan melakukan kunjungan ke luar dacrah atau menerima kunjungan dari luar daerah.

5. Kegiatan belajar mengajar dilakukan secara daring/online di seluruh lini jenjang pendidikan.

6. Kegiatan tempat ibadah diizinkan dengan pengaturan pembatasan kapasitas sebesar $50 \%$ (lima puluh persen) dengan penerapan protokol kesehatan lebih ketat.

7. Kegiatan Konstruksi tetap beroperasi $100 \%$ (seratus persen) dengan penerapan protokol kesehatan secara ketat.

8. Kegiatan di tempat hiburan, wisata dan jual beli diatur sebagai berikut:

a. Wisata air dan karaoke ditutup;

b. Wisata alam, buatan dan religi diperbolehkan dibuka, dengan ketentuan :

1) Jumlah pengunjung di dalam lokasi dibatasi paling banyak sebesar 50\% (lima puluh persen) dari kapasitas yang disediakan;

Bunyi surat edaran Bupati tentang pembelajaran daring di poin 5

Hal senada juga disampaikan oleh ketua bidang litbang Himpaudi Kabupaten Pati yakni Ibu Malihatin, M. Pd, pembelajaran model daring memang masih menjadi model pembelajaran yang dianjurkan oleh pemeritah. Akan tetapi sebenarnya juga telah dirumuskan beberapa mekanisme alternatif pembelajaran khususunya di tingkatan PAUD yang telah diinisiasi oleh Dinas Pendidikan dan Kebudayaan Kabupaten Pati. Alternatif pembelajaran tersebut diantaranya adalah dengan melakukan kombinasi model pembelajaran sebagai berikut:

1. DARING (Pembelajaran jarak Jauh Dalam Jaringan), mekanismenya dengan: (a) Menggunakan aplikasi zoom, webex, goegle meet dan apikasi lainnya; (b) Grup WhatsApp Kelas Orang Tua; (c) Grup WhatsApp Kecil Orang Tua (5 Orang) 
diperuntukkan bagi Kelompok orang tua yang tidak memiliki perangkat Handphone android dengan penunjukkan satu orang tua sebagai ketua group kecil.

Adapun teknik pelaksanaanya adalah guru menyampaikan materi dan kegiatan yang dilakukan anak-anak secara virtual pada kelompok orang tua yang diidentifikasi dapat mengikuti jadwal pembelajaran secara virtual melalui aplikasi (zoom, webex, goegle meet dan apikasi lainnya) yang dibuat satuan PAUD. Pelaporan hasil belajar anak dikirim melalui group yang dibentuk oleh satuan PAUD. Sementara itu untuk Daring yang melalui grup WhatsApp dilaksanakan dengan cara guru membuat materi pembelajaran selama satu minggu (RPPM) yang memuat materi pembelajaran kemudian dikirim ke WhatsApp Grup Kelas Orang Tua atau WhatsApp Grup Kecil Orang Tua. Selanjutnya masing - masing orang tua mengirim balik hasil kegiatan belajar anak yang berupa proses dan pengalaman belajar di rumah kepada guru dalam bentuk dokumentasi (foto, rekaman video maupun deskripsi dari orang tua). Sementara itu untuk Group WhatsApp kecil orang tua, pelaporan hasil kegiatan belajar dan bermain di rumah menjadi tanggungjawab ketua kelompok sebagai mediator untuk dikomunikasikan dan dilaporkan pada guru.

2. LURING (Pembelajaran jarak Jauh Luar Jaringan) dengan beberapa mekanisme seperti mengikuti siaran pendidikan di TVRI, mengikuti siaran pendidikan di Radio, mengkaji bahan ajar cetak, dan memanfaatkan media belajar dari lingkungan sekitar. Teknik pelaksanaan dari pembelajaran luring ini adalah guru memberikan jadwal siaran pembelajaran melalui menu yang telah disiapkan oleh pemerintah maupun swasta melalui televisi maupun radio dan atau membuat materi pembelajaran selama satu minggu sesuai dengan tema yang telah disusun dalam bentuk bahan ajar cetak, kemudian meminta orang tua datang ke sekolah tiap akhir minggu dan menyerahkan tugas tersebut ke orang tua sambil orang tua menyerahkan proses dan hasil pengalaman belajar dan bermain di rumah dari masing-masing anak pada minggu yang lalu .

3. KELAS KUNJUNG

Kelas kunjung di satuan Pendidikan Anak usia Dini yang berada di daerah zona hijau harus dilakukan dengan protokol kesehatan yang ketat dan termonitor dengan membudayakan pola hidup bersih dan sehat dalam rangka pencegahan dan pengendalian Covid-19 dengan menggunakan prosedur dan dapat dilaksanakan dengan strategi sebagai berikut : (a) Bulan Juli : Masingmasing anak kunjung 1 x dalam 1 minggu dengan jumlah 1 kelas paling banyak 5 anak; (b) Bulan Agustus: Masing-masing anak kunjung 2 x dalam 1 minggu dengan jumlah 1 kelas paling banyak 5 anak; (c) Bulan September : Masingmasing anak kunjung $3 \mathrm{x}$ dalam 1 minggu dengan jumlah 1 kelas paling banyak 10 anak; (d) Bulan Oktober : Masing-masing anak kunjung 4 x dalam 1 minggu 
dengan jumlah 1 kelas paling banyak 15 anak; (e) Bulan Nopember : Masingmasing anak kunjung $5 \mathrm{x}$ dalam 1 minggu. Dengan jumlah 1 kelas paling banyak 20 anak; (f) Bulan Desember : Masing-masing anak kunjung 6 x dalam 1 minggu dengan jumlah 1 kelas paling banyak 25 anak.

4. HOME VISIT

Kegiatan ini dilakukan dengan melalui kunjungan oleh guru kelas ke Kelompok-kelompok kecil orang tua yang telah dibentuk untuk memastikan keterlaksanaan proses Belajar Dari Rumah (BDR) dan memotivasi anak serta orang tua dalam pelaksanaan kegiatan belajar dan bermain anak di rumah. Adapun intensitas waktu kunjungan ke masing-masing kelompo kecil minimal 1 minggu 1 kali kunjungan.

Adapun kegiatan-kegiatan tersebut dapat dilaksanakan dengan ketentuan sebagai berikut: (a) Wilayah desa berada dalam Zona Hijau berdasar ketetapan satgas Covid-19; (b) Mendapat persetujuan dari Satgas Covid-19 tingkat desa (Kepala Desa) dibuktikan dengan Surat Persetujuan; (c) Mendapat persetujuan dari Satgas Covid-19 tingkat Kabupaten (Bupati) dibuktikan dengan Surat Persetujuan; (d) Mendapat persetujuan dari Komite Sekolah dibuktikan dengan Surat Persetujuan; (e) Mendapat persetujuan orang tua yang dibuktikan dengan surat pernyataan bahwa orang tua tidak keberatan anaknya mengikuti kegiatan dan apabila terjai hal-hal yang tidak diinginkan tidak menyalahkan pihak lembaga, dibuktikan dengan Surat Persetujuan; (f) Lembaga melaksanakan protokol kesehatan terkait covid-19 yang antara lain memiliki minimal 1 (satu) alat pengukur suhu badan, menyediakan untuk setiap anak 1 handsanitiser, 1 sabun, dan 4 masker, menyediakan tempat cuci tangan dengan air mengalir dengan jumlah yang cukup sehingga anak pada saat cuci tangan tidak berkerumun, guru dan orang tua yang mengantar harus memenuhi dan melaksanakan protokol kesehatan; (g) Setiap ruang kelas dapat digunakan untuk kegiatan maksimal hanya 5 anak; (h) Pengaturan tempat duduk dan jarak anak pada saat kegiatan minimal 3 meter; (i) Bagi lembaga yang melaksanakan kegiatan secara shift, maka antara shift pertama dan shift berikutnya diberi jarak waktu minimal 1 jam; (j) Penyelenggaraan kegiatan sewaktu-waktu dapat diberhentikan apabila lembaga tidak memenuhi ketentuan dan protokol kesehatan atau menurut pertimbangan Satgas covid-19 secara teknis pembelajaran tidak bisa dilaksanakan.

Peraturan ini sebenarnya diharapkan mampu menjadi solusi atas pelaksanaan pembelajaran ditingkat PAUD yang ada di Kabupaten Pati. Akan tetapi ketentuanketentuan ini ketika dikonsultasikan dengan berbagai pihak yang berwenang, belum bisa secara resmi disahkan sampai sekarang, dan pejabat yang membuat aturan kebetulan juga sudah pensiun. Dan akhirnya sampai sekarang memang belum ada ketentuan pembelajaran yang dikeluarkan secara resmi oleh dinas pendidikan dan 
kebudayaan Kabupaten Pati selain kebijakan pelaksanaan pembelajaran daring selama era new normal.

Sementara itu di bagian jenjang Pendidikan Anak Usia Dini yang lain yakni jenjang Raudhatul Athfal (RA) yang dalam hal ini di bawah koordinasi dari Kementerian Agama memiliki panduan yang telah disahkan oleh pejabat terkait dan kemudian mulai diimplementasikan oleh lembaga-lembaga RA mulai awal semester tahun ajaran ini. Hal ini seperti yang disampaikan oleh Sri Wati, S.Pd salah satu pengurus organisasi Ikatan Guru RA (IGRA) Kecamatan Kayen saat peneliti menanyakan tentang pembelajaran yang ada di lingkungan RA. Panduan pembelajaran ini seperti yang tertera dalam surat edaran nomor B2733.1/dj.i/pp.00/.00.11/08/2021 tentang panduan penyelenggaraan pembelajaran pada Madrasah (RA, MI, MTS, dan MA/MAK), Pesantren, dan lembaga pendidikan keagamaan Islam pada masa pemberlakuan pembatasan kegiatan masyarakat (ppkm) coronavirus disease 2019 (covid-19). Pedoman tersebut berisi tentang ketentuan penyelenggaraan pembelajaran pada Madrasah (RA, MI, MTs, dan MA/MAK) yang berisi: (1) Pelaksanaan pembelajaran tatap muka (PTM) terbatas di Madrasah pada Tahun Pelajaran 2021/2022 mengacu pada ketentuan dalam SKB Empat Menteri; (2) Pelaksanaan PTM terbatas di Madrasah pada Tahun Pelajaran 2021/2022 dapat dilakukan setelah mendapatkan rekomendasi dari Satuan Tugas COVID-19 setempat; (3) Selain rekomendasi dari Satuan Tugas COVID-19 juga mendapatkan rekomendasi "Siap Pembelajaran Tatap Muka (PTM) Terbatas" dari Kepala Kantor Kementerian Agama Kabupaten/Kota berdasarkan ketentuan yang diatur dalam SKB Empat Menteri dan hasil monitoring terhadap isian daftar periksa kesiapan PTM terbatas yang ditetapkan oleh Direktorat Jenderal Pendidikan Islam; (4) Prosedur pemberian rekomendasi kesiapan PTM terbatas sebagai berikut: (a) Kepala Madrasah, Guru, dan Peserta Didik RA dan Madrasah (dapat diisi oleh orang tua/wali) mengisi daftar periksa kesiapan PTM terbatas melalui laman https://siapbelajar.kemenag.go.id; (b) Kepala Kantor Kementerian Agama Kabupaten/Kota melakukan verifikasi hasil isian daftar periksa kesiapan PTM terbatas Madrasah, memperhatikan ketentuan dalam SKB Empat Menteri, berkoordinasi dengan Pemerintah Daerah dan Satuan Tugas COVID-19 terkait dengan status Level Wilayah dan diperbolehkannya pelaksanaan PTM terbatas di wilayah kerjanya, maka selanjutnya melalui laman https://siapbelajar.kemenag.go.id memberikan rekomendasi penyimpulan kesiapan pelaksanaan PTM terbatas bagi satuan pendidikan madrasah; (c) Rekomendasi sebagaimana dimaksud dalam huruf 2), menyatakan kesiapan pelaksanaan PTM terbatas di Madrasah sebagai berikut: Siap PTM terbatas, Siap PTM terbatas dengan syarat; atau memilih Belajar Dari Rumah; (d) Dalam hal rekomendasi dinyatakan "Siap PTM Terbatas", orang tua peserta didik tetap dapat memilih pembelajaran PTM terbatas atau pembelajaran jarak jauh/belajar dari rumah bagi anaknya. 
Dengan adanya edaran tersebut, lembaga-lembaga PAUD yang berbentuk RA mulai melakukan pembelajaran tatap muka secara terbatas. Misalnya dengan menerapkan sistem shift pada waktu pembelajarannya dan membagi siswa ke dalam kelompok kecil guna meminimalisir kerumunan siswa. Awalnya kegiatan ini dimulai dengan kelas kunjung di rumah siswa atau guru. Kemudian lambat laun kegiatan ini pun dikembalikan lagi ke sekolah.

Selain itu menjalin kesepakatan dengan keluarga juga diupayakan semaksimal mungkin untuk mencari solusi yang tepat, serta mendapatkan jaminan dan komitmen dari orangtua wali saat melepas anaknya ke sekolah. Ini seperti yang peneliti temukan di RA Hidayah Tayu di mana orangtua siswa dibuatkan semacam surat pernyataan jika berkeinginan untuk menyekolahkan anaknya di sekolah. Contoh surat pernyataannya bisa di lihat di gambar berikut.

Adanya opsi untuk sekolah tatap muka langsung pun disambut baik oleh para orangtua yang selama ini suah jenuh dan lelah saat mendampingi anaknya belajar daring selama ini. Seperti yang disampaikan oleh Ibu Puji Lestari yang memiliki 2 anak usia PAUD. Saat medampingi anaknya belajar terkadang ia merasa tidak sabar dan jenh, di samping itu keterbatasan alat/media yang digunakan untuk belajar daring juga menjadi persoalan. Ibaratnya $1 \mathrm{hp} \mathrm{untuk} \mathrm{sekolah} 2$ orang, belum lagi saat ada kegiatan lain yang bersamaan dengan aktivitas kerjanya yang juga sebagai alah satu karyawan di sebuah kantor. Meskipun sebenarya ia juga khawatir dengan kesehatan anaknya jika dibiaran sekolah tatap muka, tapi kekhawatiran akan hilangnya masa belajar anaknya menjadi alasan yang tidak bisa ditawar lagi, karena bagaimanapun ia merasa jika hasil dari pembelajaran daring sangat berbeda dengan pembelajaran luring (langsung). Selain itu ia juga bersyukur saat ini pandemi sudah mulai mereda, jadi ia sudah sedikit merasa aman.

Hal senada juga disampaikan oleh Atmim nurona, salah satu murid RA yang mengaku senang bisa bersekolah dengan tatap muka lagi. Karena dengan tatap muka bisa langsung bertemu gurunya, teman-temannya dan bisa megeksplorasikan dirinya langsung bukan dari melihat layar hp yang kadang jika terlalu lama membuat matanya sakit.

\section{Pembelajaran Anak Usia Dini di Kabupaten Pati}

Berdasarkan hasil penelitian yang telah tertuang di atas setidaknya ada 2 hal besar yang menjadi warna dari pembelajaran anak usia dini yang ada di Kabupaten Pati. Kedua hal tersebut yaitu:

1. Pada lembaga PAUD yang berada di garis koordinasi langsung dengan Dinas Pendidikan dan Kebudayaan Kabupaten Pati seperti Kelompok Bermain (KB), Taman Kanak-Kanak (TK), Tempat Penitipan Anak (TPA), satuan pendidikan sejenis masih menggunakan pembelajaran daring dalam setiap kegiatan pembelajarannya. Hal ini mengingat belum ada edaran resmi dari pihak terkait tentang kebolehan untuk melakukan pembelajaran secara tatap muka langsung 
atau luring (luar jaringan). Pembelajaran daring yang dilakukan lebih banyak menggunakan media HP baik itu melalui grup WA sekolah, video call, maupun lewat zoom maupun google meet. Ini bisa dimaklumi karena memang Dinas Pendidikan barangkali lebih ingin berhati-hati terhadap perkembangan kasus covid-19, sehingga belum bisa memutuskan secara resmi untuk melakuakn Pendidikan secara tatap muka.

Diberlakukannya kebijakan ini tentu juga memiliki beberapa implikasi dan dampak. Misalnya masih dirasa kurang optimalnya pemahaman siswa terhadap materi yang diajarkan, belum meratanya kemampuan logistik/alat yang dimiliki oleh masing-masing siswa, orangtua kesulitan mendampingi belajar anak, dan lain sebagainya.

2. Pada lembaga PAUD yang berada di bawah naungan Kementerian Agama yakni Raudhatul Athfal (RA) sudah diperbolehkan untuk melakukan pembelajaran tatap muka meskipun masih secara terbatas sesuai dengan surat edaran nomor B-2733.1 /dj.i/ pp.00/.00.11/08/2021 tentang panduan penyelenggaraan pembelajaran pada Madrasah (RA, MI, MTS, dan MA/MAK), Pesantren, dan lembaga pendidikan keagamaan Islam pada masa pemberlakuan pembatasan kegiatan masyarakat (PPKM) coronavirus disease 2019 (covid-19). Adanya edaran ini disambut dengan baik oleh para pengelola RA dengan mulai menerapkan pembelajaran tatap muka terbatas dan selalu menggunakan protokol Kesehatan yang ketat, setelah sebelumnya masih menggunakan pembelajaran daring secara menyeluruh.

Awalnya pembelajaran dimulai dengan melakukan kelas kunjung/home visit di tempat para siswa. Guru mendatangi kediaman siswa masing-masing kemudian melakukan kegiatan belajar mengajar di sana. Setelah tahapan itu kemudian pembelajaran diganti dengan beberapa kelompok kecil dan pembelajaran dilakukan di rumah masing-masing guru terdekat. Kemudian setelah terbangaun kesepakatan antara orangtua dengan lembaga, pembelajaran kemudian dipindah kembali ke sekolah dengan model shift atau pembagian waktu belajar. Jadi misalnya kelas A itu ada 16 anak, maka kelas tersebut dibagi menjadi 2 waktu belajar. Yang kelas A1 pukul 07.00 sampai 09.00, kelas yang A2 mulai pukul 10.00-12.00 WIB. Saat ini pola ini yang dirasa cukup efektif untuk belajar anak usia dini selama pandemi. Ini senada dengan hasil penelitian dari Widyawati tentang strategi pembelajaran Pendidikan anak usia dini di masa pandemi covid-19 di Kecamatan Sibulue Kabupaten Bone yang menyimpulkan jika pembelajaran tatap muka terbatas dengan mengatur jam masuk siswa, dapat menjaga minat anak usia dini untuk belajar secara langsung dan menyenangkan bersama para guru-gurunya. (Widyawati, 2020)

Menurut salah satu ahli, pola pembelajaran dengan tatap muka menjadi pola pembelajaran yang pas dan sesuai dengan karakterik anak usia dini yang memiliki rasa ingin tahu yang besar, merupakan pribadi yang unik, suka 
berfantasi dan berimajinasi, masa potensial untuk belajar, memiliki sikap egosentris, memiliki rentan daya konsentrasi, dan merupakan bagian dari makhluk sosial (Tatminingsih, 2010). Selain itu anak usia dini merupakan anak yang sedang berada dalam proses perkembangan, baik fisik, intelektual, sosial, emosional, dan bahasa. Jika hanya melalui pembelajaran daring/online tentu anak tidak bisa secara leluasa mengeksplorasi rasa ingin tahunya, imajinasinya, mudah goyah konsentrasinya dan kurang bisa merangsang perkembangan intelektual, sosial, emosional dan juga bahasanya. Karena anak hanya terbatas berinteraksi secara daring, tidak bisa langsung baik dengan gurunya maupun teman-temannya.

\section{Faktor Pendukung dan Penghambat Pembelajaran Anak Usia Dini di Kabupaten Pati}

Jika berpedoman kepada pembahasan yang sudah disajikan di atas, bisa dikatakan jika secara garis besar pembelajaran AUD di Kabupaten Pati terbagi menjadi 2 pembelajaran. Pembelajaran daring dan pembelajaran tatap muka terbatas. Pembelajaran yang dilakukan secara daring memiliki hambatan pada kefektifan pembelajaran dan tingkat pemahaman siswa dalam menangkap materi dan mengembangkan potensi diri anak secara langsung. Akan tetapi dengan adanya pembelajaran daring ini, resiko anak untuk tertular covid-19 terbilang minim. Dan ini bisa menjadi salah satu cara membentengi anak agar tidak terkena penyakit menular ini. Selain itu model pembelajaran daring juga didukung oleh pemerintah dan dinas Pendidikan setempat.

Pembelajaran tatap muka terbatas telah didukung oleh pemangku kebijakan tingkat Kementerian Agama dan saat ini orang tua juga sudah mulai mempercayakan anaknya lagi untuk berproses di sekolah. Ini bisa menjadi sandaran ataupun alasan agar pembelajaran tatap muka secara normal bisa mulai diberlakukan di semua jenjang, baik yang di bawah naungan Kementerian Agama maupun yang ada di bawah naungan Dinas Pendidikan. Meskipun pembelajaran ini memiliki resiko bagi anak tertular, tapi dengan penerapan protokol kesehatan yang baik pasti akan mampu meminimalisir kondisi tersebut. Penerapan protokol ini misalnya dengan mewajibkan guru dan anak untuk selalu memakai masker, selalu menggunakan handsanitizer saat pembelajaran, menjaga jarak, dan selalu menjaga kebersihan diri maupun lingkungan tempat belajar.

\section{KESIMPULAN}

Pembelajaran anak usia dini yang ada di Kabupaten Pati memiliki 2 bentuk yaitu: Pada lembaga PAUD yang berada di garis koordinasi langsung dengan Dinas Pendidikan dan Kebudayaan Kabupaten Pati seperti Kelompok Bermain (KB), Taman Kanak-Kanak (TK), Tempat Penitipan Anak (TPA), satuan pendidikan sejenis masih menggunakan pembelajaran daring dalam setiap kegiatan pembelajarannya. $\mathrm{Hal}$ ini mengingat belum ada edaran resmi dari pihak terkait tentang kebolehan 
untuk melakukan pembelajaran secara tatap muka langsung atau luring (luar jaringan).

Sedangkan pada lembaga PAUD yang berada di bawah naungan Kementerian Agama yakni Raudhatul Athfal (RA) sudah diperbolehkan untuk melakukan pembelajaran tatap muka meskipun masih secara terbatas sesuai dengan surat edaran nomor B-2733.1 /dj.i/ pp.00/.00.11/08/2021 tentang panduan penyelenggaraan pembelajaran pada Madrasah (RA, MI, MTS, dan MA/MAK), Pesantren, dan lembaga pendidikan keagamaan Islam pada masa pemberlakuan pembatasan kegiatan masyarakat (PPKM) coronavirus disease 2019 (covid-19). Adanya edaran ini disambut dengan baik oleh para pengelola RA dengan mulai menerapkan pembelajaran tatap muka terbatas dan selalu menggunakan protokol Kesehatan yang ketat, setelah sebelumnya masih menggunakan pembelajaran daring secara menyeluruh.

Faktor pendukung dan penghambat pembelajaran lebih kepada aturan pemerintah menyikapi fenomena tersebut. Sayangnya sampai saat ini masih terjadi perbedaan yang mendasar antara kebijakan yang ditetepakn di lingkungan Dinas Pendidikan yang menaungi KB, TK, TPA, dan lain sebagainya, dengan Kementerian Agama yang menanungi RA.

\section{DAFTAR PUSTAKA}

Aan, S. d. (2009). Metode Penelitian Kualitatif. Bandung: Alfabeta.

Arif S.Sadiman, d. (2014). Media pendidikan Pengertian, Pengembangan dan Pemanfaatannya. Depok: PT. Raja Grafindo Persada.

Komalasari, K. (2013). Pembelajaran Kontekstual, Konsep \& Aplikasi. Bandung: PT Rafika Aditama.

Montessori, M. (2017). The Absorbent Mind, terj.Daryanto. Yogyakarta: Pustaka Pelajar.

SaifuddinAzwar. (2013). Metode Penelitian. Yogyakarta: Pustaka Pelajar.

Samino. (2010). Kepemimpinan Pendidikan. Surakarta: Fairuz Media.

Sugiyono. (2010). Metode Penelitian Kualitatif \& Kuantitatif. Bandung: Alfabeta.

Tatminingsih, S. (2010). Hakikat Anak Usia Dini. Modul Pembelajaran.

Warsita, B. (2011). Teknologi Pembelajaran, Landasan dan Aplikasinya. Jakarta: Rineka Cipta.

Widyawati. (2020). Strategi Pembelajaran Pendidikan Anak Usia Dini di Masa Pandemi Covid 19. Educhild, Vol. 2 No. 1, 29. 
Yovita, A. ( 2020). Lebih dari 849 Juta Siswa di Dunia Belajar di Rumah. Jakarta: Kompas.id. 